\title{
Biphasic Release of Thyrotropin in Response to Thyrotropin- Releasing Hormon (TRH) from Rat Anterior Pituitary Cells in Vitro: Possible Dependence on Protein Synthesis
}

\author{
Kunio SHIOTA, KeIJI YOSHIDA, Tsuneo MASAKI, \\ Masahiro KAWASE, Ryo NAKAYAMA and Katsuichi SUdO \\ Central Research Division, Takeda Chemical Industries, Ltd., \\ Juso-Honmachi, Yodogawa-ku, Osaka 532
}

\begin{abstract}
Mechanisms related to the biphasic release of TSH were studied using primary cultured cells of the rat anterior pituitary gland on micro-carrier beads in a superfusion system. Release of TSH in response to continuous exposure to TRH exhibited a biphasic pattern; the first phase was characterized by a rapid, transient and high-rate release (phase I) and the second phase by a chronic and low-rate release (phase II). The shift of the release from phase I to phase II occurred by treatment with TRH at concentrations from submaximal to maximal. When the $\mathrm{Ca}^{2+}$ concentration in the medium was decreased, the phase I release was partially inhibited, while the phase II release was completely inhibited, suggesting a difference between the mechanisms in phase I and phase II release. The phase I release was not suppressed by cycloheximide. This protein synthesis-independent release of phase I seemed to be linked to the intracellular releasable pool of TSH. The phase II release was suppressed by the presence of a protein synthesis inhibitor. After the phase II release was suppressed by cycloheximide, the magnitude of phase I release in response to re-exposure to TRH markedly decreased. The decreased phase I release in response to TRH was observed with the cells which were previously stimulated by high $\mathrm{K}^{+}$instead of $\mathrm{TRH}$, suggesting that the decrease in the response of phase I reflects the depletion of a releasable pool of TSH rather than homologous desensitization of thyrotrophs with TRH. These results suggest that the phase I release of TSH depends on a portion of the previously prepared-releasable pool while phase II release depends on previously prepared plus newly prepared pools of TSH. Replenishment of the releasable TSH pool was considered to involve protein synthesis.
\end{abstract}

During constant stimulation by an appropriate agent, there is a biphasic response of several protein hormones including $\mathrm{LH}$ (Tixier-Vidal and Gourdgi, 1981), PRL and TSH (Morin et al., 1975; Bremner et al., 1977; Schrey et al., 1977; Connors et al.,

Received December 12, 1983
1981) in vivo and in vitro. It seems, therefore, that there might be a common release mechanism for all of these hormones. Bremner et al. (1977) reported that constant intravenous infusions of TRH resulted in a $\mathrm{TSH}$ release in two phases in healthy humans and suggested that these two phases of release may reflect the existence of two 
pools of TSH in the cells. Schrey et al. (1977) and Connors et al. (1981) demonstrated that continuous exposure to TRH resulted in a biphasic release of TSH in vitro using dispersed cells of the rat anterior pituitary. We also demonstrated that TRH as well as its analog (DN-1417) caused biphasic release of TSH from superfused pituitary cells (Shiota et al., 1984). Since the profile of the biphasic release caused by a maximally effective concentration of TRH was different from that by high $\mathrm{K}^{+}(60 \mathrm{mM})$ solution, there seems to be a specific action of TRH related to the biphasic release (Shiota et al., 1984). Though protein synthesis is theoretically expected to play an important role in the second-phase release, as shown in the case of LH (Pickering and Fink, 1976; Kercret and Duval, 1978 ; Liu and Jackson, 1978 ; Bourne and Baldwin, 1980), the relation of the first and the second release of TSH in connection with protein synthesis is poorly understood.

Though a superfusion technique appears suitable for investigating the transient phenomena of hormone release, the acquisition of pertinent data is difficult due to considerable inter-experimental variation when a one-channel superfusion system is used. We attempted to characterize the biphasic release of TSH in a specially designed multi-channel superfusion system in which data can be compared within an experiment and to clarify the dependence of this on protein synthesis. The effect of extracellular $\mathrm{Ca}^{2+}$ was also studied.

\section{Materials and Methods}

\section{Animals}

Male Sprague-Dawley rats (ages 9-12 weeks, CLEA Japan Inc.) were maintained in a cotrolled environment at $24 \pm 1^{\circ} \mathrm{C}$ with a $14 \mathrm{~h}$ light$10 \mathrm{~h}$ dark cycle (lights on at $0730 \mathrm{~h}$ ) and had free access to water and standard laboratory chow.

\section{Reagents}

TRH was synthesized in the Chemistry Loboratories of the Takeda Central Research Division (Fukuda et al., 1980). Other materials were obtained from the following sources : cycloheximide, BSA(fraction V) and ethyleneglycol-bis( $\beta$-aminoethyl ether) $\mathbf{N}, \mathbf{N}, \mathrm{N}^{\prime}, \mathrm{N}^{\prime}$-tetraacetic acid (EGTA) from Wako Pure Chemical Industries, LTD. (Japan); DNA (type I from calf thymus), and gentamicin sulfate from Sigma Chemical Co. (St. Louis, Mo) ; pancreatin, Hepes, DNAse, Dulbecco's Modified Eagle Medium, penicillin and streptomycin from Grand Island Biological Co. (Grand Island, NY); collagenase (type II) from Millipore Corporation (Freehold NJ); and Cytodex $^{\mathrm{TM}} 1$ from Pharmacia Fine Chemicals (Sweden).

\section{Primary culture of anterior pituitary cells and superfusion}

The primary culture of the cells and superfusion were performed by a modification of methods reported elsewhere (Shiota et al., 1984; Shiota and Wiest, 1979; Smith and Vale, 1980). Briefly, rat anterior pituitary glands were quartered and washed with Hepes buffer $(137 \mathrm{mM}$ $\mathrm{NaCl}, 5 \mathrm{mM} \mathrm{KCl}, 0.7 \mathrm{mM} \mathrm{Na} \mathrm{HPO}_{4}, 25 \mathrm{mM}$ Hepes and $50 \mu \mathrm{g} / \mathrm{ml}$ gentamicin sulfate, $\mathrm{pH}$ 7.3). The tissue was dispersed by incubation first with a buffer containing $0.4 \%$ collagenase, $0.4 \%$ BSA, $10 \mu \mathrm{g} / \mathrm{ml}$ DNAse and $0.2 \%$ glucose, and then with $10 \%$ pancreatin. Dulbecco's Modified Eagle Medium (DMEM) supplemented with 10 $\%$ fetal bovine serum, $20 \mathrm{mM}$ Hepes, $50 \mathrm{U} / \mathrm{ml}$ penicillin and $50 \mu \mathrm{g} / \mathrm{ml}$ streptomycin was added to bring the concentration to $3 \times 10^{5}$ cells $/ \mathrm{ml}$. Cytodex ${ }^{\mathrm{TM}} 1$, swollen in Hepes buffer $(0.1 \mathrm{~g} / 2.5$ $\mathrm{ml}$ ), was mixed with $100 \mathrm{ml}$ lots of the cell suspension and incubated for 4-5 days under a saturated atmosphare of $5 \% \mathrm{CO}_{2}-95 \%$ air in a $\mathrm{CO}_{2}$ incubator at $37^{\circ} \mathrm{C}$.

Cells attached to the Cytodex ${ }^{\mathrm{TM}} 1$ beads $(0.9-$ $1.4 \times 10^{7}$ cells/column) were introduced in a $0.7 \times$ $4 \mathrm{~cm}$ polypropylene/glass column (Bio-Rad Laboratories, Richmond, $\mathrm{CA}$ ), and the columns were placed in a $37^{\circ} \mathrm{C}$ water bath. The superfusion medium consisted of DMEM (pH 7.3) containing $1.85 \mathrm{~g} \mathrm{NaHCO}_{3} /$ liter supplemented with $20 \mathrm{mM}$ Hepes, without serum and antibiotics. In certain experiments, Krebs Improved Ringer I bicarbonate solution (McKenzie and Dawson, 1969) was used as a superfusion medium (KIRI). A high $\mathrm{K}^{+}(60 \mathrm{mM})$ solution was prepared by substituting $\mathrm{KCl}$ for $\mathrm{NaCl}$ to the extent necessary. A 
low $\mathrm{Ca}^{2+}$ medium was prepared by simply omitting $\mathrm{CaCl}_{2}$, with or without adding EGTA (16 $\mu \mathrm{M}$ ). The Microperpex ${ }^{\circledR}$ peristaltic pumps (LKBProdukter, Sweden) maintained the flow of the medium through the cell column at a constant rate of $0.25 \mathrm{ml} / \mathrm{min}$. The medium was allowed to flow down the side wall of the column. A lag period of $13.5 \pm 0.6 \mathrm{~min}(n=4)$ was needed for the peptide to reach the fraction collector. Two to four columns were run in parallel and one served as the control in every experiment. The cell columns were allowed to adjust to the superfusion environment for $120 \mathrm{~min}$ before sample collection. The effluent was collected every $10 \mathrm{~min}$. The samples were stored at $-20^{\circ} \mathrm{C}$ until assay. At the end of the superfusion, cells were recovered and suspended in $1 \mathrm{ml}$ saline and stored at $-20^{\circ} \mathrm{C}$ until assayed for TSH and DNA. TRH and cycloheximide were dissolved in the medium to give the final concentration shown under Results. TRH in the superfusion medium proved to be stable under these experimental conditions, because $96 \%$ of the initial concentration of TRH was recovered $6 \mathrm{~h}$ after peptide was added to the medium at room temperature (Shiota et al., 1984).

\section{Assays}

An aliquot of the cell suspension was homogenized in $2 \mathrm{ml} 50 \mathrm{mM}$ Tris- $\mathrm{HCl}$ buffer containing $12.5 \mathrm{mM}$ sodium borate and $5 \mathrm{mM}$ EDTA, pH 8.9 (Jahn et al., 1982) and sonicated with a Sonic Dismembrator (ARTEK System Corp., Farmingdale, NY) at dial 60 for $20 \mathrm{sec}$. After centrifugation $(3,000 \mathrm{rpm}, 20 \mathrm{~min})$, an aliquot of the supernatant was used for the determination of cellular TSH content. The DNA content in the cells was measured by a modification of the method of Burton (1956), using type I calf thymus DNA as the standard.

The amount of TSH was measured in duplicate by the double antibody radioimmunoassay using a kit provided by the NIAMDD Rat Pituitary Hormone Distribution Program. Iodination of TSH with ${ }^{125} \mathrm{I}$ was performed by the chloramine-T method. All samples of the medium were assayed in duplicate using $200 \mu \mathrm{l}$ undiluted samples. The results were expressed in terms of NIAMDD-rat TSH-RP-1 standard. The intraassay coefficient of variation was $5.7 \%(n=5)$ and the inter-assay coefficient of variation was $16.6 \%(\mathrm{n}=9)$.

\section{Results}

Each result shown is a representative experiment out of two or three similar experiments with similar results.

Effects of continuous exposure to fixed or various doses of TRH on TSH release.

Four columns were run in parallel, and the TSH responses to fixed or various doses of TRH were examined (Fig. 1). DNA content was $104.4 \pm 2.6 \mu \mathrm{g} /$ column $(\mathrm{n}=4)$ in the experiment. The intra-experiment coefficient of variation of the DNA content was less than $5 \%$ throughout. The cells were first exposed to TRH (100 $\mathrm{nM}$ ) for $100 \mathrm{~min}$ and the responses were nearly identical for all columns. During the continuous exposure to $\mathrm{TRH}$, a high rate of $\mathrm{TSH}$ release was initially observed within $6.5 \mathrm{~min}$ after the addition of TRH (the time-lag, $13.5 \mathrm{~min}$ was deducted), for about $40 \mathrm{~min}$ (phase I); thereafter the hormone release decreased rapidly to a constant lower rate of secretion (phase II) even with continuous exposure to TRH. Phase II release lasted as long as the cells were exposed to TRH; when TRH was withdrawn, the TSH release decreased to the basal level.

Sixty min after the end of the first exposure to TRH, the cells were reexposed for $60 \mathrm{~min}$ to varying concentrations of TRH $(0,1,5$ and $100 \mathrm{nM})$ and the dosedependent increase in phase I and phase II release of TSH was obtained, indicating that the rapid decrease in phase I release or shift to phase II release was not due to nonspecific damage of the cells as there was a re-occurrence of the response. The maximally effective concentration of TRH was $100 \mathrm{nM}$, since $1 \mu \mathrm{M}$ of $\mathrm{TRH}$ produced no further increase in the hormone release (data not shown).

Effects of continuous exposure to TRH in low
$\mathrm{Ca}^{2+}$ medium
To evaluate the extracellular $\mathrm{Ca}^{2+} \mathrm{de}-$ 


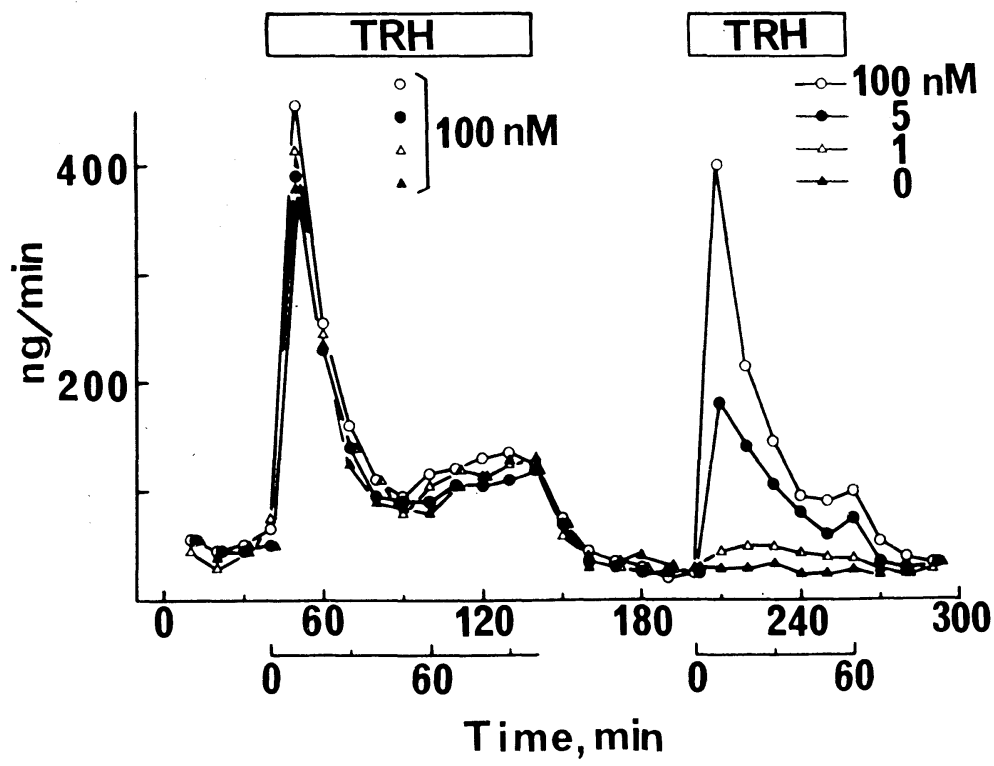

Fig. 1. TSH release in response to continuous exposure to TRH. The cells were first exposed to TRH (100 $\mathrm{nM}$ for $100 \mathrm{~min}$ ) followed by various doses $(0,1,5,100 \mathrm{nM}$ for 60 $\mathrm{min})$ at $60 \mathrm{~min}$ interval. Four columns were run in parallel with a flow rate of $0.25 \mathrm{ml} / \mathrm{min}$ and the effluent was collected every $10 \mathrm{~min}$. Time scales indicate the period after the start of either sample collection or TRH stimulation.

pendency of the biphasic release of TSH, the cells were exposed to TRH $(100 \mathrm{nM})$ for $180 \mathrm{~min}$ in a low $\mathrm{Ca}^{2+}$ medium (Fig. 2A). Exposure to the low $\mathrm{Ca}^{2+}$ medium was initiated $40 \mathrm{~min}$ before the TRH stimulation. Basal release of TSH was not reduced in low $\mathrm{Ca}^{2+}$ medium. During the exposure to $\mathrm{TRH}$, there was a slight increase in release in the period corresponding to the phase I, but the phase II release was completely inhibited under conditions of low $\mathrm{Ca}^{2+}$. EGTA (16 $\mu \mathrm{M})$, a chelating agent, was added simultaneously with $\mathrm{TRH}$ in the low $\mathrm{Ca}^{2+}$ medium (Fig. 2B). A slight increase in TSH in the phase I period was still apparent.

Effects of a protein synthesis inhibitor on $\mathrm{TSH}$ release

In order to further characterize the biphasic release of $\mathrm{TSH}$, the dependency of each phase release on protein synthesis was studied. The effect of the protein synthesis inhibitor, cycloheximide $(\mathrm{CX})$, on the release of TSH was then examined (Fig. 3). The cells were exposed to TRH $(100 \mathrm{nM})$ for $180 \mathrm{~min}$ in the presence or absence of $7 \mu \mathrm{M} \mathrm{CX}$, a dose that inhibited [methyl $\left.{ }^{3} \mathrm{H}\right]$ methionine incorporation of primary culture of pituitary cells into trichloroacetic acid precipitable material by about $80 \%$ in static incubation for 2 or $4 \mathrm{hr}$. When the cells were exposed simultaneously to $\mathrm{CX}$ and $\mathrm{TRH}$, there was no inhibitory effect on phase I release of TSH, while phase II release was reduced. When exposure to $\mathrm{CX}$ $(7 \mu \mathrm{M})$ was started $120 \mathrm{~min}$ before the continuous exposure to TRH, the basal and the phase I releases of TSH were not reduced but the phase II release was again suppressed (data not shown), confirming that the phase I release was refractory to the proteinsynthesis inhibitor and the result was not due to a CX action time lag. The dependency on protein synthesis appeared at a fixed time of TRH stimulation-about $80 \mathrm{~min}$ after the initiation of TRH stimulation-regardless of the duration of the $\mathrm{CX}$ pretreatment. The net amounts of TSH released during TRH exposure were about $6 \%$ (control) and $5 \%$ (in the presence of $\mathrm{CX}$ ) of the original immunoreactive TSH content in the cells. At the end of the experiment, a $293 \mu \mathrm{g} /$ column and $273 \mu \mathrm{g} /$ column of immunoreactive TSH remained in the control 

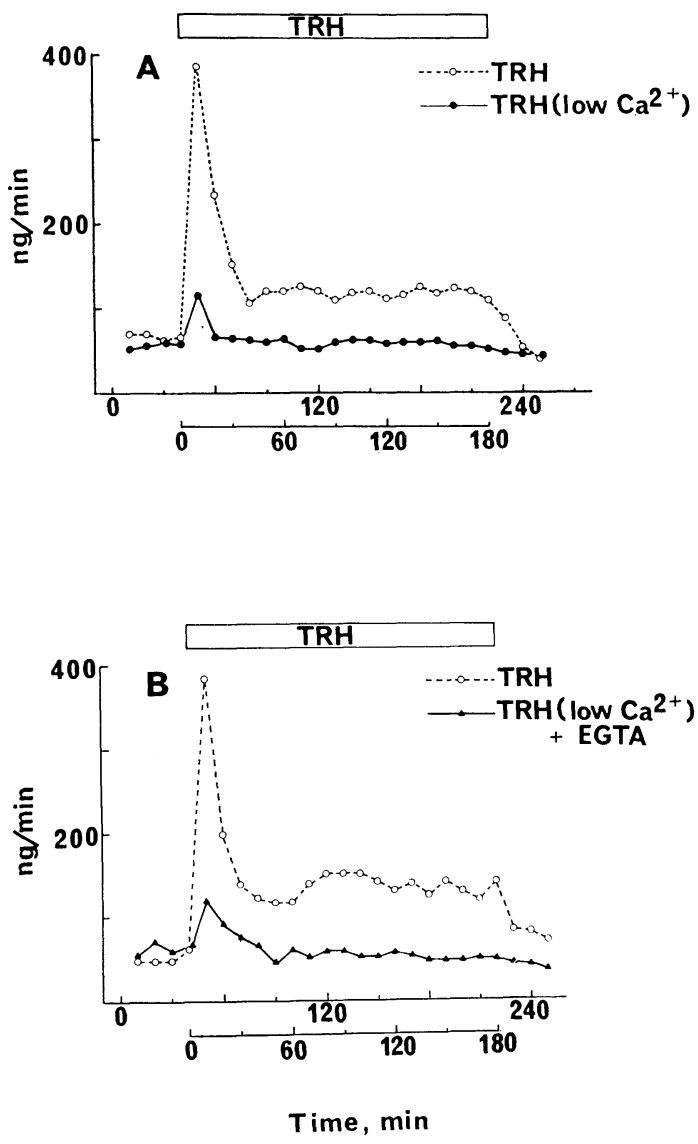

Fig. 2. TSH release in response to continuous exposure to TRH $(100 \mathrm{nM}$ for $180 \mathrm{~min})$ in normal KIRI or in low $\mathrm{Ca}^{2+}$ KIRI with or without EGTA. A, exposure to the low $\mathrm{Ca}^{2+}$ medium was started $40 \mathrm{~min}$ before the TRH exposure; $\mathrm{B}$, exposure to the low $\mathrm{Ca}^{2+}$ medium was started $40 \mathrm{~min}$ before the exposure to TRH plus EGTA $(16 \mu \mathrm{M})$.

and the CX treated cells, respectively. Thus, the phase II but not the phase I release of TSH in response to initial exposure to TRH seems to depend on protein synthesis.

TSH release induced by pulse exposure to $T R H$ and the effects of $C X$

To examine the necessity of TRH stimulation for the appearance of the phase II release, the length of TRH exposure was

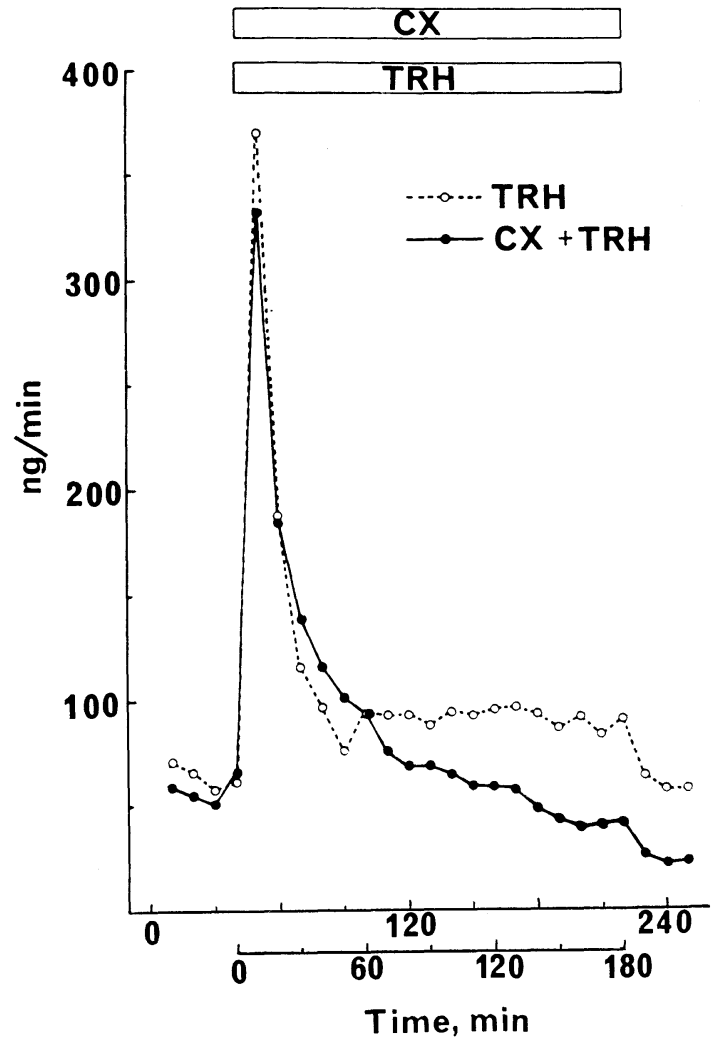

Fig. 3. TSH release in response to continuous exposure to TRH (100 $\mathrm{nM}$ for $180 \mathrm{~min})$ in the presence or absence of cycloheximide (7 $\mu \mathrm{M})$. The cycloheximide was present in the medium from the start of exposure to TRH.

shortened to $20 \mathrm{~min}$ (Fig. 4A). There was an initial rapid and transient increase but the release corresponding to phase II was not observed by this pulse exposure, indicating that continuous exposure to $\mathrm{TRH}$ was necessary for the biphasic release of TSH.

A pulse exposure to TRH (100 nM, 20 min) was then repeated three times at 30 min intervals in the presence or absence of CX $(7 \mu \mathrm{M})$ and the results were compared with those for continuous exposure to TRH (Fig. 4B). Though TSH releases induced by the second and third exposures to TRH were smaller than the release induced by 

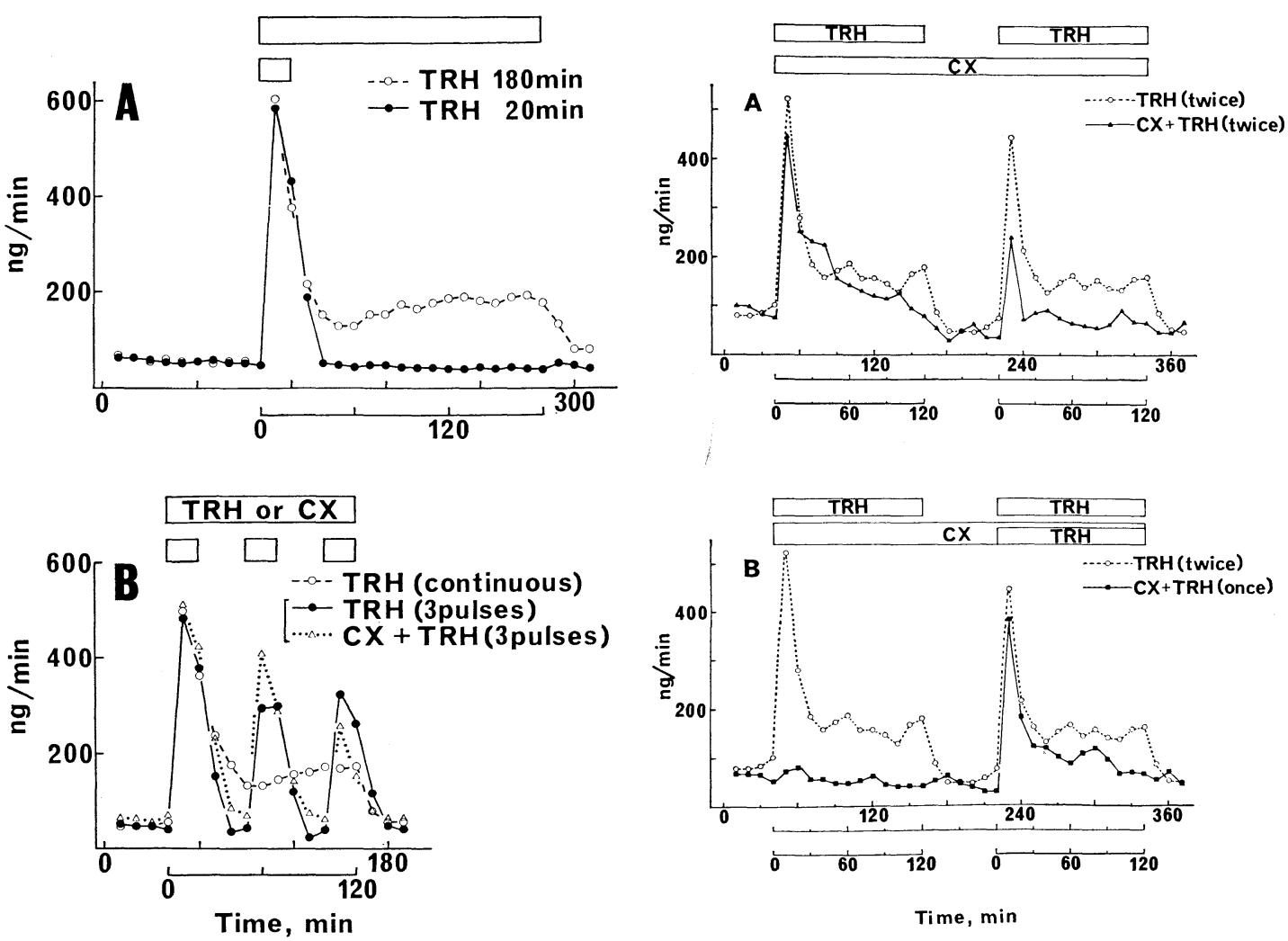

Fig. 4. A, TSH release in response to a pulse (20 min) or continuous (180 $\mathrm{min})$ exposure to TRH $(100 \mathrm{nM})$. B, TSH release in response to three-pulse exposure $(20 \mathrm{~min})$ to TRH $(100$ $\mathrm{nM})$ at $30 \mathrm{~min}$ intervals in the presence or absence of cycloheximide $(7 \mu \mathrm{M})$. Cycloheximide was continuously present from the first exposure to TRH. TSH release by threepulse exposure was also compared with that by continuous exposure to TRH (100 nM for $120 \mathrm{~min})$.

the first exposure, they were higher than the phase II release induced by the continuous stimulation and therefore more likely to be the phase I release (Fig. 4B). In the presence of $\mathrm{CX}$, the repeated TRH pulses again induced 3 phase I-like releases, though there was a tendency toward a gradual decrease in the magnitude of the third release (Fig. 4B).

Fig. 5. TSH release in response to two continuous exposures to TRH in the presence or absence of cycloheximide $(7 \mu \mathrm{M})$. A, continuous exposure to TRH $(100 \mathrm{nM}$ for 120 min) was repeated twice at $60 \mathrm{~min}$ interval in the presence or absence of cycloheximide; $\mathrm{B}$, TRH stimulation (100 $\mathrm{nM}$ for $120 \mathrm{~min})$ was started $180 \mathrm{~min}$ after the initiation of cycloheximide exposure. The response with two continuous exposures to TRH in the absence of cycloheximide is included for comparison.

Effects of a protein synthesis inhibitor on TSH release induced by repeated prolonged stimulation

In the cells in which the phase II release was suppressed by treatment with a protein synthesis inhibitor, the response to the following TRH stimulation was examined. Continuous exposure to TRH (100 nM, 120 min) was repeated twice at 60 min intervals in the presence or absence of CX (Fig. 5). 


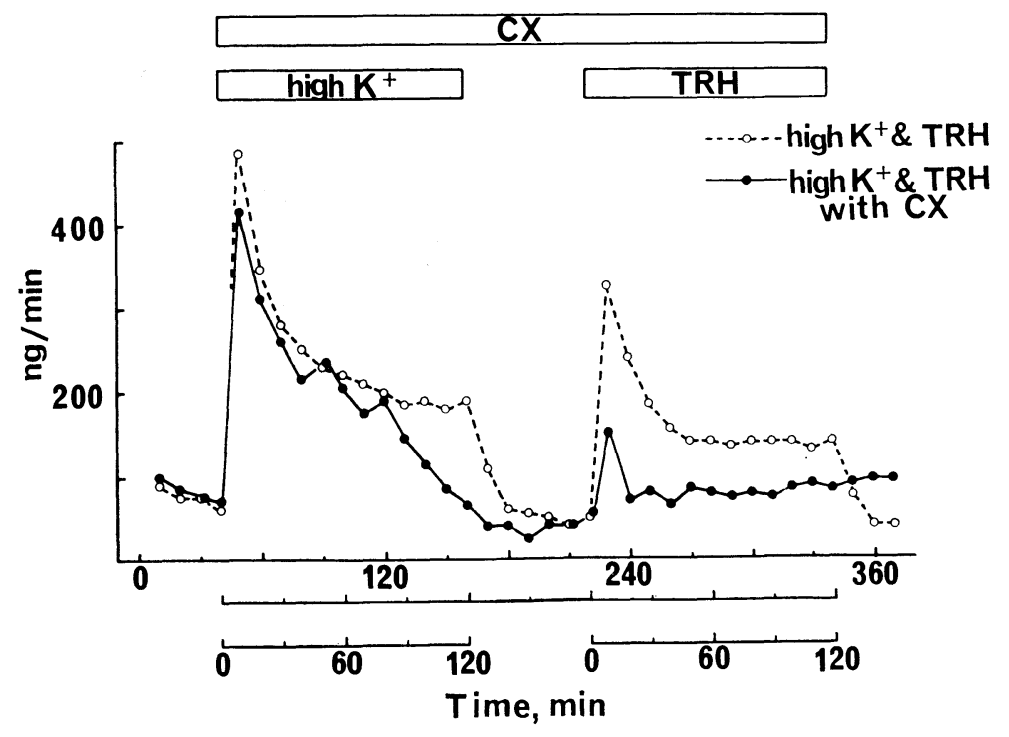

Fig. 6. TSH release in response to high $\mathrm{K}^{+} \mathrm{KIRI}$ (60 $\mathrm{mM} \mathrm{KCl}$ for $120 \mathrm{~min}$ ) followed by TRH (100 $\mathrm{nM}$ for $120 \mathrm{~min}$ ) exposure at $60 \mathrm{~min}$ interval in the presence or absence of cycloheximide $(7 \mu \mathrm{M})$.

During the first exposure to $\mathrm{TRH}$, the phase I release of TSH was not reduced in the precence of CX $(7 \mu \mathrm{M})$, but phase II secretion was reduced (Fig. 5A). On the second exposure to TRH, the phase $\mathrm{I}$ as well as the phase II release of TSH was reduced in the presence of CX. When the first exposure to TRH was omitted and the TRH stimulation was started $180 \mathrm{~min}$ after the initiation of $\mathrm{CX}$ exposure, the phase I release of TSH was not suppressed but the phase II was suppressed during exposure to TRH (Fig. 5B). Therefore, the reduced response of phase I release of TSH in response to the second exposure to TRH was not due to nonspecific damage of the cells by prolonged treatment with $\mathrm{CX}$.

To determine whether the attenuated response to the second TRH stimulation may be due to a specific action of the previous exposure to TRH or simply the depletion of TSH in the cells, the first stimulation was performed by prolonged exposure to high $\mathrm{K}^{+}$ solution instead of TRH. The cells were first exposed to high $\mathrm{K}^{+}(60 \mathrm{mM})$ for 120 min and then exposed to TRH $(100 \mathrm{nM})$ in KIRI for $120 \mathrm{~min}$ either in the presence or absence of CX (Fig. 6). Continuous exposure to the high $\mathrm{K}^{+}$medium resulted in a marked increase in TSH release. The phase I release of $\mathrm{TSH}$ induced by high $\mathrm{K}^{+}$was not affected by the presence of CX $(7 \mu \mathrm{M})$, however, the later release corresponding to the phase II release was reduced. As in the results in Fig. 5A, both phase I and phase II releases induced by the TRH exposure following high $\mathrm{K}^{+}$stimulation were considerably reduced in the presence of CX.

\section{Discussion}

The biphasic profile of TSH release was reproducible in the present study, thus confirming and extending previous studies (Schrey et al., 1977 ; Connors et al., 1981 ; Shiota et al., 1984).

Generally, only a small percentage of the TSH content in the cells was released and large amounts of hormone remained in the cells at the end of superfusion with TRH. Immunoreactive TSH in the cells may consist of heterogenous forms of hormone (Yora, 1979) and/or those at various stages of synthesis; there seems to be a limited pool of releaseable TSH. The phase I release of 
TSH dropped sharply without staying long at the peak level and the phase II release followed. This shift from phase I to phase II was observed not only with a maximum dose $(100 \mathrm{nM})$ but also with a submaximum dose $(5 \mathrm{nM})$ of $\mathrm{TRH}$, and the amount of hormone released during phase I period by the small dose of TRH was smaller than that released by the maximum dose. Thus, the amount of hormone released during phase I does not seem to be a factor regulating the shift. Exposure to a high $\mathrm{K}^{+}$ concentration produced a higher peak of TSH compared with that seen with a maximum stimulation dose of TRH (Shiota et al., 1984), and intermittent stimulation of TRH caused phase I-like releases that were higher than the phase II release even in the presence of CX. These results indicated that the potential amount of releasable pool of hormone is usually greater than that released during the phase I, and also suggested that the shift from phase I release to phase II is caused through a mechanism other than exhaustion of the previously preparedreleasable pool.

The importance of extracellular $\mathrm{Ca}^{2+}$ (Schrey et al., 1978; Tashjian et al., 1978; Thorner et al., 1980; Geras et al., 1982) and intracellular $\mathrm{Ca}^{2+}$ mobilization (Schrey et al., 1978; Gershengorn, 1980; Dust and Martin, 1982; Geras and Gershengorn, 1982 ; Geras et al., 1982) have been reported in the release mechanism of pituitary hormones. It has not been reported, however, whether the importance of $\mathrm{Ca}^{2+}$ resides in the phase I or the phase II release of TSH. We found that the phase II release of TSH completely depends on extracellular $\mathrm{Ca}^{2+}$, while the phase I release seems to consist of two components, extracellular $\mathrm{Ca}^{2+}$-dependent and -independent. This partial dependence of the phase I release seems to be specific for $\mathrm{TRH}$, because high $\mathrm{K}^{+}$solution did not produce any increase in TSH in the low $\mathrm{Ca}^{2+}$ solution, as shown in our previous study using the same superfusion system
(Shiota et al., 1984). Though the possibility that a very low concentration of $\mathrm{Ca}^{2+}$ remains in the superfusion-column cannot be excluded during the early period of superfusion, these results suggest the existence of different mechanisms in the phase I and phase II releases. The shift in TSH release from phase I to phase II may relate to the change in $\mathrm{Ca}^{2+}$ action mechanism.

This is the first demonstration that the phase II release of TSH involves protein synthesis. Though the protein synthesisdependent release in $\mathrm{LH}$ has been reported (Pickering and Fink, 1976; Kercret and Duval, 1978 ; Liu and Jackson, 1978 ; Bourne and Baldwin, 1980), the significance of the dependency in the dynamics of the hormone secretion is still unknown. Since the shift from phase I to phase II release occurs before complete depletion of a previously prepared-releasable pool, it is possible that the phase II release in an early period is also consuming the releasable pool that had been prepared. Because both the release of phase I and the initial part of phase II were independent of protein synthesis, the release from the previously prepared-releasable pool of TSH seems to be independent of de novo protein synthesis. Thyrotrophs can release TSH without de novo protein synthesis when TRH stimulation is given intermittently; the phenomenon was only observed before complete depletion of the releasable pool. The decrease in phase II release by CX resulted in attenuation of the phase I release induced by the following TRH stimulation, suggesting that the previously prepared pool of TSH is consumed during the previous prolonged TRH stimulation but not restored in the presence of CX. Though homologous desensitization by prolonged exposure to hypothalamic peptides has been proposed (Hinkle and Tashjian, 1975; Gershengorn, 1978 : Bourne and Baldwin, 1980 ; Badger et al., 1983), the attenuated response does not seem to depend on the down regulation by TRH because a similar result was obtained 
when TSH release was first stimulated by $\mathrm{K}^{+}$instead of TRH. Furthermore, the period of the first exposure $(120 \mathrm{~min})$ to $\mathrm{TRH}$ seems to be too short to cause a significant reduction in the receptor in the present study. Long term treatment with TRH was required to cause a significant reduction in the receptor in in vitro experiments performed by others (Hinkle and Tashjian, 1975; Gershengorn, 1978). For example, a decrease to $75 \%$ of the control was observed after $48 \mathrm{~h}$ exposure to TRH in $\mathrm{GH}_{3}$ cells (Hinkle and Tashjian, 1975) and a decrease to $70 \%$ at $24 \mathrm{~h}$ exposure in mouse pituitary thyrotropic tumor cells (Gershengorn, 1978). In addition, our results showed that $\mathrm{CX}$ treatment decreases the response; this is in contrast to the report by Hinkle and Tashjian (1975) who demonstrated that the receptor loss was reversed by the treatment with CX. Therefore, these observations strongly suggested that the attenuated response of the phase I release in the phase II blocked cells by $\mathrm{CX}$ depends on the depletion of a releasable pool of TSH but not on the downregulation by TRH. The releasable pool must be replenished to continue the release after depletion of the pool, and the mechanism of the replenishment seems to involve protein synthesis.

In relation to the replenishment mechanism, de novo synthesis of TSH might be important, since TRH reportedly stimulates the synthesis as well as the release of TSH (Wilber, 1971; Vale et al., 1972; Marshall et al., 1981). In the incubation study of rat hemipituitaries with $\left[{ }^{14} \mathrm{C}\right]$ alanine and $\left[{ }^{14} \mathrm{C}\right]$ glucosamine, Wilber (1971) found that TRH stimulated the release of newly synthesized TSH and that CX inhibited the synthesis. From the studies of GH release using $\mathrm{GH}_{3}$ cells, Stachura (1982) proposed that there is a hormone pool which is outside the direct path of the intracellular hormone flow from synthesis to release, and once discharged by the stimulation with $\mathrm{K}^{+}$or dibutyryl cyclic AMP, the hormone compo- nent is rapidly reconstituted with synthesized hormone. Such a mechanism as in the case of $\mathrm{GH}$ release from $\mathrm{GH}_{3}$ cells may be involved in TSH release. Another possibility is that the synthesis of protein is involved in the mechanism of the secretory process including, processing, glycosylation (Wilber, 1971 ; Weintraub et al., 1980; Chinn and Habener, 1981; Weintraub et al., 1983), packaging hormones within secretory granules and migration of the granule toward the plasma membrane as shown in morphological studies (Wilber and Spicer, 1980).

In conclusion, concerning the biphasic release of TSH in response to continuous exposure to $\mathrm{TRH}$, the results described above suggested that 1) the phase I release involves both extracellular $\mathrm{Ca}^{2+}$-dependent and -independent mechanisms, and the phase II release was extracellular $\mathrm{Ca}^{2+}$-dependent, 2) the phase I release shifts to the phase II release through a mechanism other than depletion of the releasable hormone, 3) the phase I release depends on a portion of a previously prepared-releasable pool and the phase II release depends on both previously prepared and newly prepared pool of $\mathrm{TSH}$ and, 4) the replenishment process of releasable TSH pool involves de novo protein synthesis.

\section{Acknowledgements}

We thank Dr. A.F. Parlow and the NIAMDD Rat Pituitary Hormone Distribution Program for the gift of the rat TSH RIA kit. This work was supported in part by a grant for new drug development from the Ministry of Health and Welfare of Japan. We are also grateful to Dr. M. Takahashi (Tokyo University) for valuable suggestions, to Drs. M. Fujino, C. Hatanaka and $\mathrm{O}$. Nishimura for provision of TRH, to Ms. Y. Akinaga for technical assistance, and to Ms. M. Ohara and Dr. J. R. Miller for reading the manuscript. 


\section{References}

Badger, T. M., J. S. Loughlin and P. G. Naddaff (1983). The luteinizing hormone-releasing hormone (LHRH)-desensitized rat pituitary: luteinizing hormone responsiveness to LHRH in vitro. Endocrinology 112, 793-799.

Bourne, G. and D. M. Baldwin (1980). Extracellular $\mathrm{Ca}^{++}$-independent and -dependent components of the biphasic release of $\mathrm{LH}$ in response to luteinizing hormone-releasing hormone in vitro. Endocrinology 107, 780-788.

Bremner, W. J., R. Abreu, J. R. Stockigt, D. M. De Kretser and H. G. Burger (1977). Pituitary-thyroid responses to 4-hour constant infusions of thyrotropin releasing hormone in man. J. Clin. Endocrinol. Metab. 45, 981986.

Burton, K. (1956). A study of the conditions and metabolism of the diphenylamine reaction for the colorimetric estimation of deoxyribonucleic acid. Biochem. J. 62, 315-323.

Chinn, W.W. and J.F. Habener (1981). Thyroidstimulating hormone subunits: evidence from endoglycosidase-H cleavage for late presecretory glycosylation. Endocrinology 108, 16281633.

Connors, J. M., K. C. Wright, A. M. Judd, C. M. Liu and G. A. Hedge (1981). Dynamics and regulation of TSH secretion by superfused anterior pituitary cells. Hormone Res. 14, 1-17.

Drust, D. S. and T. F. J. Martin (1982). Thyrotropin-releasing hormone rapidly and transiently stimulates cytosolic calcium-dependent protein phosphorylation in $\mathrm{GH}_{3}$ pituitary cells. J. Biol. Chem. 257, 7566-7573.

Fukuda, N., O. Nishimura, M. Shikata, C. Hatanaka, M. Miyamoto, Y. Saji, R. Nakayama, M. Fujino and Y. Nagawa (1980). Synthesis and pharmacology of TRH analogs to separate central nervous action from endocrine activity. Chem. Pharm. Bull. 28, 16671672.

Geras, E. J. and M. C. Gershengorn (1982). Evidence that TRH stimulates secretion of TSH by two calcium-mediated mechanisms. Am. J. Physiol. 242, E109-E114.

Geras, E., M.J. Rebecchi and M.C. Gershengorn (1982). Evidence that stimulation of thyrotropin and prolactin secretion by thyrotropinreleasing hormone occur via different calcium- mediated mechanisms: studies with verapamil. Endocrinology 110, 901-906.

Gershengorn, M. C. (1978). Bihormonal regulation of the thyrotropin-releasing hormone receptor in mouse pituitary thyrotropic tumor cells in culture. J. Clin. Invest. 62, 937-943.

Gershengorn, M. C. (1980). Thyrotropin releasing hormone stimulation of prolactin release: evidence for a membrane potential-independent, $\mathrm{Ca}^{2+}$-dependent mechanism of action. J. Biol. Chem. 255, 1801-1803.

Hinkle, P.M. and A.H. Tashjian (1975). Thyrotropin-releasing hormone regulates the number of its own receptors in the $\mathrm{GH}_{3}$ strain of pituitary cells in culture. Biochemistry 14, 3845-3851.

Jahn, G. A., G. A. Machiavelli, L. E. Kalbermann, I. Szijian, G. E. Alonso and J. A. Burdman (1982). Relationships among release of prolactin, synthesis of DNA and growth of the anterior pituitary gland of the rat: effects of oestrogen and sulpiride. J. Endocrinol. 94, 1-10.

Kercret, H. and J. Duval (1978). Gonadoliberinpromoted release of godadotropins and increased sensitivity of the pituitary by oestradiol17 $\beta$. J. Steroid Biochem. 9, 761-766.

Liu, T. C. and G. L. Jackson (1978). Modifications of luteinizing hormone biosynthesis and release by gonadotropin-releasing hormone, cycloheximide and actinomycin D. Endocrinology 103, 1253-1263.

Marshall, Jr., M. C., D. Williams and B. D. Weintraub (1981). Regulation of de novo biosynthesis of thyrotropin in normal, hyperplastic, and neoplastic thyrotrophs. Endocrinology 108, 908-915.

McKenzie, H. A. and R. M. C. Dawson (1969). pH and buffers: physiological media. In : Data for Biochemical Research (R. M. C. Dawson, D. C. Elliot, W. H. Elliot and K. M. Jones, eds.), Oxford University Press, New York, pp. 476-508.

Morin, A., A. Tixier-Vidal, D. Gourdji, B. Kerdelhue and D. Grouselle (1975). Effect of thyreotrope-releasing hormone (TRH) on prolactin turnover in culture. Mol. Cell. Endocrinol. 3, 351-373.

Pickering, A. J. M. C. and G. Fink (1976). Priming effect of luteinizing hormone releasing factor : in vitro and in vivo evidence consistent with its dependence upon protein and RNA synthesis. J. Endocrinol. 69, 373-379. 
Schrey, M. P., B. L. Brown and R. P. Ekins (1977). Studies on the control and dynamics of thyrotropin secretion from isolated adenohypophyseal cells. Mol. Cell. Endocrinol. 8, 271-282.

Schrey, M. P., B. L. Brown and R. P. Ekins (1978). Studies on the role of calcium and cyclic nucleotides in the control of TSH secretion. Mol. Cell. Endocrinol. 11, 249-264.

Shiota, K. and W. G. Wiest (1979). On the mechanism of prolactin stimulation of steroidgenesis. In : Ovarian Follicular and Corpus Luteum Function. (C. P. Channing, J. M. Marsh and W.A. Sadler, eds.), Plenum Press, New York, pp. 169-178.

Shiota, K., K. Yoshida, C. Noguchi and R. Nakayama (1984). In vitro thyrotropin release with thyrotropin releasing hormene and an analog, DN-1417. Acta Endocrinol. (Copenh) 106, 71-78.

Smith, M. A. and W. W. Vale (1980). Superfusion of rat anterior pituitary cells attached to cytodex beads: validation of a technique. Endocrinology 107, 1425-1431.

Stachura, M. E. (1982). Sequestration of an early-releasable pool of growth hormone and prolactin in $\mathrm{GH}_{3}$ rat pituitary tumor cells. Endocrinology 111, 1769-1777.

Tashjian, Jr., A. H., M. E. Lomedico and D. Maina (1978). Role of calcium in the thyrotropin-releasing hormone-stimulated release of prolactin from pituitary cells in culture. Biochem. Biophys. Res. Commun. 81, 798-806.

Thorner, M. O., J. T. Hackett, F. Murad and R. M. MacLeod (1980). Calcium rather than cyclic AMP as the physiological intracellular regulator of prolactin release. Neuroendocrino- $\log y$ 31, 390-402.

Tixier-Vidal, A. and D. Gourdji (1981). Mechanisms of action of synthetic hypothalamic peptides on anterior pituitary cells. Physiol. Rev. 61, 974-1011.

Vale, W., G. Grant, M. Amoss, R. Blackwell and R. Guillemin (1972). Culture of enzymatically dispersed anterior pituitary cells : functional validation of a method. Endocrinology 91, 562-572.

Weintraub, B. D., B. S. Stannard, D. Linnekin and M. Marshall (1980). Relationship of glycosylation to de novo thyroid-stimulating hormone biosynthesis and secretion by mouse pituitary tumor cells. J. Biol. Chem. 255, 5715-5723.

Weintraub, B. D., B. S. Stannard and L. Meyers (1983). Glycosylation of thyroid-stimulating hormone in pituitary tumor cells : influence of high mannose oligosaccharide units on subunit aggregation, combination, and intracellular degradation. Endocrinology 112, 1331-1345.

Wilber, J. F. (1971). Stimulation of ${ }^{14}$ C-glucosamin and ${ }^{14} \mathrm{C}$-alanine incorporation into thyrotropin by synthetic thyrotropin-releasing hormone. Endocrinology 89, 873-877.

Wilbur, D. L. and S. S. Spicer (1980). Pituitary secretory activity and endocrinophagy. In : Synthesis and Release of adenohypophyseal Hormones (M. Jutisz and K. W. McKerns, eds.), Plenum Press, New York, pp. 167-186.

Yora, T., S. Matsuzaki, Y. Kondo and N. Ui (1979). Changes in the contents of multiple components of rat pituitary thyrotropin in altered thyroid states. Endocrinology 104, 1682-1685. 